\title{
Observation of Sex Chromatin in Exhumed Bones, Evaluation of their Diagnosis Value
}

\author{
Observación de la Cromatina Sexual en Osamentas Exhumadas, \\ Evaluación de su Valor Diagnóstico
}

"Patricia Muñoz; "Ignacio Roa; *"Daniela Zavando \& ${ }^{* * * *}$ Iván Suazo Galdames

MUÑOZ, P.; ROA, I.; ZAVANDO, D. \& SUAZO, G. I. Observation of sexual chromatin in exhumed bones, evaluation of their diagnosis value. Int. J. Morphol., 30(2):588-591, 2012.

SUMMARY: Observation of sexual chromatin has shown to be very helpful in gender forensic diagnosis. In the present study we analyzed the diagnosis performance of the method in, non-treated or treated with conventional bone techniques, exhumed bone pieces. We used long bones of male and female individuals, the method applied is described in Suazo et al. (2010). In the non-treated exhumed pieces, the general accuracy of the method was $75 \%$, while in the treated pieces the method was inapplicable due to the lack of cells in the tissue. Our results suggest that it is possible to determine the sex of aged human bones buried under different conditions through a fast and simple histological method, but the treatment with physical and chemical means eliminates the remaining cells in the bone tissue.

KEYWORDS: Sexual Chromatin; Determination of Sex; Bones; Forensic Analysis.

\section{INTRODUCTION}

Construction of the biological profile is the first step to identify human skeletal remains; it includes the diagnosis of sex, age, nutritional state, height and any other data that may allow an approximation to the characteristics of the subject alive. In this respect, forensic anthropology has various methods applicable to bone pieces and dental pieces; nevertheless, the determination of sex with bone remains is complex when the remains are fragmented or present special pathological conditions (Suazo et al., 2008; 2009).

A simple histological method, used for the determination of sex, is to observe the presence of sex chromatin (Barr chromatin) in somatic cells (Vera et al., 1986). The dimorphic trait consists of a small body visible through optic microscopy, present in the nucleus of nerve cells of females, but absent in that of the males (Barr et al., 1950). Barr chromatin was closely associated to the nucleolus and at the beginning it was called "nucleolar satellite" (Mittwoch, 1964). Sex chromatin can be stained with a great number of nuclear stains (Barr, 1959). Some staining techniques of common use employ cresyl violet, thionine (Klinger, 1957), haematoxylin-eosin of selected material such as skin biopsies, aceto-orcein, carbol fuchsin and fluorescence (Duffy et al., 1991). The fact that sex chromatin can be stained through Feulgen technique after acid hydrolysis, and that it has an affinity with methyl green instead of pyronin (Lindsay \& Barr, 1955), indicates that they have DNA. Sex chromatin is a small well-defined body capable of being intensely stained with certain nuclear stains. The size of sex chromatins is approximately 1 micron in diameter. Sex chromatins are found in almost $40 \%$ of female cells and are known as chromatin-positive, and in male cells, they are known as chromatin-negative.

In men, the presence of sex chromatin has been extensively studied in the nervous system (Barr et al., 1950), polymorphonuclear leukocytes (Davidson \& Winn, 1961), the epidermis and the mucosa membrane, and it has also been observed in the cells of amniotic fluid, placenta and fetal membranes (Klinger, 1957), cells of the retina, and oral mucosa (Dixon \& Torr, 1956) and of dental pulp (Duffy et al.). In reference to the above, Suazo et al. (2010), determined a "gold standard" from the observation of 50 cells of dental pulp preparation, reporting $100 \%$ accuracy for the diagnosis of sex, method that would be useful even in cases where the pieces are subject to high temperatures (Suazo et al., 2011).

\footnotetext{
* Departamento de Ciencias Básicas Biomédicas, Universidad de Talca, Chile.

** Universidad Autónoma de Chile.

**** Facultad de Medicina, Universidad Diego Portales, Santiago, Chile.
} 
In bone tissue, it is also possible to observe sex chromatin (Vernino \& Laskin, 1960), although the diagnosis value of its observation when the skeletal remains have been exhumed has not been described. Thus, the purpose of this study is to assess the diagnosis value of the sex discrimination method based on the presence of sex chromatin in exhumed bones and the effect that bone technical processing has.

\section{MATERIAL AND METHOD}

A study was designed to evaluate the diagnosis test. . The sample consisted of long bone blocks obtained through saw cuts of the epiphysis, with minimum dimensions of $1 \mathrm{~cm}$ wide, long and deep, which were divided in 4 groups.

Group A: Bones exhumed from mass graves and ossuaries, stored without any physical or chemical treatment for cleaning or disinfection.

Group B: Bones exhumed from mass graves and ossuaries, treated with conventional bone technical procedures (Rodrigues, 2005), used for teaching.

In both cases the bones were donated to the laboratory in accordance with the principles of Código Sanitario de la República de Chile and the general law for cemeteries.

Twenty (20) bones from each group were selected. We included only pieces with anatomic integrity, without macroscopic morphological alterations. Bones that presented porosity, or those that due to their weight made it evident that the decalcification process was advanced, were included. Each bone was submitted to anthropometric evaluation for the diagnosis of sex, as proposed by Martin \& Saller (1957). The sex diagnosed through this procedure was considered the gold standard to calculate the performance of the test.

From each bone, a block of tissue was obtained with the minimum dimensions of $1 \mathrm{~cm}$ wide, long, and deep. The samples obtained were fixed on Millonig formalin modified by Carlson (pH: 7.2 and $0.1 \mathrm{M}$ in phosphate buffer), decalcified in $1 \%$ formic acid and then processed through conventional histological technique and included in Paraplast Plus (SigmaÒ); in this way, histological cuts were obtained: colored, 5um thick, which were studied under a light microscope with a magnification of $100 \mathrm{X}$.

Once the histological processing was complete, 5 histological slides were obtained for each bone through systematic random sampling. The slides were observed under a trinocular microscope CX21 (Olympus (®) with a magnification of 100X; 50 cells per slide were evaluated. To render sex chromatin test positive, at least one cell in the slide that presented chromatin condensation in the nuclear circumference was to be observed, in accordance with the method previously described by Suazo et al. (2010) for dental pulp. With these data, the method's general accuracy was calculated in the treated and non-treated exhumed bones, as well as the performance for men and women.

\section{RESULTS}

\section{Results of the evaluation of non-treated exhumed bones.} In spite of the limited cellular density of the samples, the observation of the 50 cells proposed, through a systematic round of the slides, was possible. In this group, the general accuracy of the method was $75 \%$.

Diagnosis in men: No sex chromatin positive cells were observed in any of the samples of individuals of male sex, thus, all the bones of male individuals were diagnosed as such. For this reason, the method sensitivity for men was $100 \%$.

Diagnosis for women: In the total of the samples observed, $50 \%$ showed sex chromatin positive cells, thus the method showed a 50\% sensitivity for the diagnosis of women. In the same way, in the remaining $50 \%$ of the sample, no sex chromatin condensation was observed in the visible cells. Figure 1 shows a microphotography of a bone cut of a nontreated female bone.

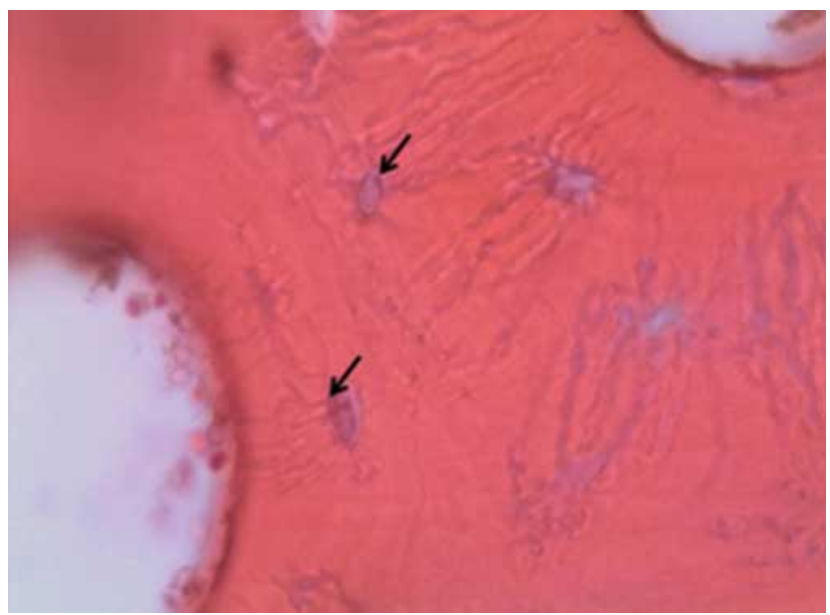

Fig. 1. Microphotography of the bone cut of a female individual of non-treated exhumed bone. The arrows show osteocytes in their lacunas; notice the presence of sex chromatin. 100X Hematoxylineosin. 
Results of the evaluation of treated exhumed bones. According to the sample selection criteria, the sample was constituted by 20 long exhumed bones treated through conventional bone techniques for their use in teaching anatomy, 10 of which belonged to male individuals and 10 to female individuals. It was not possible to observe cells or cellular remains in the lacunas; therefore, the method was deemed as inapplicable. The bone presented a lower affinity to staining, the osteons central canals were empty. This may be seen in Figure 2.

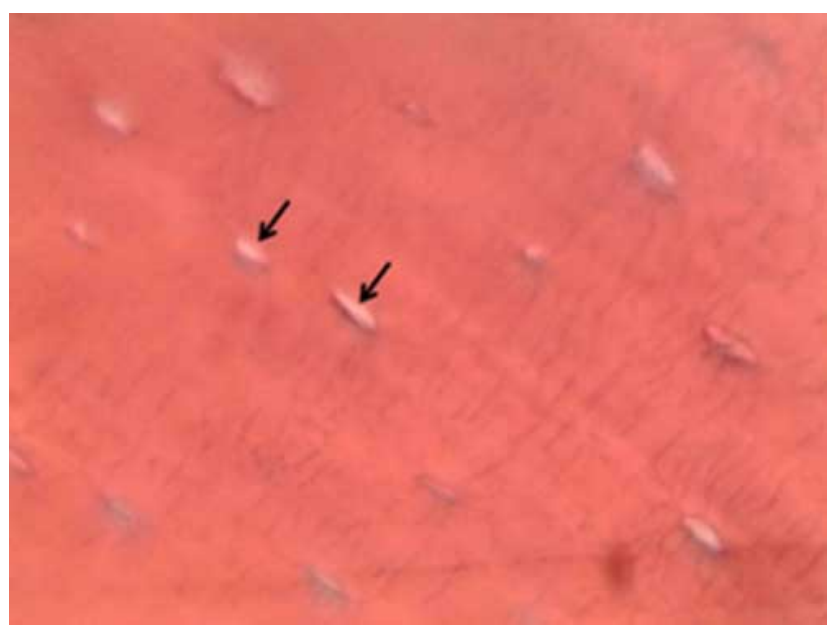

Fig. 2. Microphotography of the bone cut of a female individual exhumed bone, treated with conventional bone techniques for use in teaching. The arrows show the central canals of the osteons empty, notice the absence of cells or cellular remains. 100X Hematoxylin-eosin.

\section{DISCUSSION}

The observation method of sex chromatin presented a 75\% accuracy in samples of non-treated exhumed bones, which is lower to that reported by Suazo et al. (2010) in dental pulp. In this aspect, the dates of death of the pieces obtained from mass graves and ossuaries are not determined, but through the normal procedures of cemetery administration, it is possible they may date from more than 10 years ago. This is quite relevant since in spite of the influence that time and the burial conditions have on the conservation of tissues, it was possible to observe the presence of osteocytes, even allowing the observation of subcellular organs such as sex chromatin. The protection of the compact osteons osteocytes, the degree of calcification of the matrix, together with appropriate soil conditions, could favor the feasibility of these cells for the diagnosis of sex, even many years after death has taken place. This also occurs in pulp tissue for it is protected by the hard tissues of the tooth (Suazo et al., 2011), but the feasibility of sex chromatin is considerably lower, for Seno \& Ishizu (1973) it is 5 months, while for Whittaker et al. (1975), it is 5 weeks.

In relation to the bones treated with conventional bone techniques, the method was deemed as inapplicable, since it was not possible to visualize cells in the cuts analyzed. It is important to highlight the fact that in bones treated with chemicals no cells were observed, but in bones that were not treated buried 10 or more years ago, it was possible to observe these cells. This may be explained by the fact that the decomposition of the bodies depends on the appearance of various necrophagous insects that takes place at different times, as well as the depth of the grave, composition of the soil, humidity, temperature, mechanical strains, etc., which influence the corpse. The decomposition of the corpse through cadaveric fauna greatly depends on the climate in which the bodies are buried. In this way, there are occasions in which the bodies have been buried for 9 or 10 years, in humid environments for example, but do not show any sign of decomposition at bone level (Rodríguez, 1994).

This study suggests that it is possible to determine the sex of exhumed human bones of long aged and in different burial conditions, through a fast and simple histological method.

MUÑOZ, P.; ROA, I.; ZAVANDO, D. \& SUAZO, G. I. Observación de la cromatina sexual en osamentas exhumadas, evaluación de su valor diagnóstico. Int. J. Morphol., 30(2):588-591, 2012.

RESUMEN: La observación de la cromatina sexual ha demostrado ser útil en el diagnóstico forense del sexo. En este estudio analizamos el rendimiento diagnóstico del método en piezas óseas exhumadas no tratadas y tratadas mediante osteotécnica convencional. Utilizamos muestras de huesos largos de individuos de sexo masculino y femenino, el método se aplicó de acuerdo a lo descrito por Suazo et al., (2010). En las piezas exhumadas no tratadas la exactitud general del método fue del $75 \%$, mientras que en las piezas tratadas el método resultó inaplicable, debido a la ausencia de células en el tejido. Nuestros resultados sugieren que es posible determinar el sexo en osamentas humanas exhumadas de larga data y en diferentes condiciones de enterramiento, mediante un método histológico rápido y sencillo, pero que el tratamiento por medios físicos y químicos elimina las células remanentes en el tejido óseo.

Palabras Clave: Cromatina sexual; Determinación del sexo; Osamentas; Análisis forense. 


\section{REFERENCES}

Barr, M. L.; Bertram, L. F. \& Lindsay, H. A. The morphology of the nerve cell nucleus, acording to sex. Anat. Rec., 107:283, 1950 .

Barr, M. L. Sex chromatin and phenotype in man. Science, 130(3377):679-85, 1959.

Davidson W. M. \& Winn, S.. The relationship between the sex nodule and the sex chromosomes. In Proceedings of the Conference on Human Chromosomal Abnormalities. Brit. Med. J., 2(6), 1961.

Dixon A. D \& Torr, J. B. D. Sex chromatin in oral smears. Brit. Med. J., 2(4996):799-800, 1956.

Duffy, J. B.; Waterfield, D. J. \& Skinner, M. C. Isolation of tooth pulp cells for sex chromatin remains. Foren. Sci. Int., 49:127-41, 1991.

Klinger. H. P. The sex chromatin in fetal and meternal portions of the human placenta. Acta Anat., 30-7:371, 1957.

Lindsay, H. A, \& Barr, M. L. Further observations on the behavior of nuclear structures during depletion and restoration of Nissl material. J. Anat., (89):47-62,1955.

Martin, R. \& Saller, K. Lehrbuch der anthropologie. Fischer, Stuttgart, 1957.

Mittwoch U. Sex Chromatin. J. Med. Genet., 1:50-76, 1964.

Rodríguez J. Introducción a la Antropología Forense. Análisis e identificación de restos óseos humanos. Departamento de Antropología, Universidad Nacional de Colombia, 1994. p.p. 1-15.

Rodrigues H. Técnicas anatómicas. $3^{\circ}$ Ed. Vitória. 2005.

Seno, M. \& Ishizu. H. Sex identification of human tooth Int. J. Forensic Dent., 1(8):8-11, 1973.

Suazo, G. I.; Zavando, D. \& Smith, R. L. Evaluating accuracy and precision in morphologic traits for sexual dimorphism in malnutrition human skull: a comparative study. Int. J. Morphol., 26:877-81, 2008.

Suazo, G. I.; Zavando D. \& Smith R. Performance evaluation as a diagnostic test for traditional methods for forensic identification of sex. Int. J. Morphol., 27:381-6, 2009.
Suazo, G. I,: Roa, H. I. \& Cantín, L. M.. Sex chromatin in dental pulp. Performance of diagnosis test and gold standard generation. Int. J. Morphol., 28:1093-6, 2010.

Suazo, G. I.; Flores, A.; Roa, I.; Cantín, M. \& Zavando, D. Sex determination by observation of Barr body in teeth subjected to high temperatures. Int. J. Morphol., 29(1):199-203, 2011.

Vera, D.; Youlton, R. \& Be, C. Cromatina de Barr: Análisis de su valor actual. Rev. Chil. Pediatr., 57:506-9, 1986.

Vernino, D. \& Laskin, D. Sex Chromatin in Mammalian Bone. Science, 132(3428):675-6, 1960.

Whittaker, D. K.; Llewelyn, D. R. \& Jones, R. W. Sex Determination from necrotic pulpal tissue. Brit. Dent. J., 139:403-5, 1975.

Correspondence to:

Prof. Dr. Iván Suazo Galdames

Department of Morphofunction

Faculty of Medicine

Universidad Diego Portales

Santiago - CHILE

Email:ivan.suazo@udp.cl

Received: 10-03-2012

Accepted: 16-04-2012 